PERM JOURNAL OF PETROLEUM AND MINING ENGINEERING

ВЕСТНИК ПНИПУ. ГЕОЛОГИЯ. НЕФТЕГАЗОВОЕ И ГОРНОЕ ДЕЛО

ISSN 2224-9923

Volume/ Toм 16 №3 2017

http://vestnik.pstu.ru/geo/

УДК 550.822.2/.3:622.276

Article / Статья

( PNRPU / ПНИПУ, 2017

\title{
METHOD FOR EVALUATION OF OIL DISPLACEMENT COEFFICIENT BASED ON CONVENTIONAL CORE ANALYSIS
}

\section{Evgeniy A. Gladkikh, Grigoriy P. Khizhnyak, Vladislav I. Galkin, Nikita A. Popov ${ }^{1}$}

Perm National Research Polytechnic University (29 Komsomolskiy av., Perm, 614990, Russian Federation)

${ }^{1}$ PermNIPIneft branch of LUKOIL-Engineering LLC in Perm (29 Sovetskoy Armii st., Perm, 614066, Russian Federation)

\section{СПОСОБ ОЦЕНКИ КОЭФФИЦИЕНТА ВЫТЕСНЕНИЯ НЕФТИ НА ОСНОВЕ СТАНДАРТНЫХ ИССЛЕДОВАНИЙ КЕРНА}

\section{Е.А. Гладких, Г.П. Хижняк, В.И. Галкин, Н.А. Попов ${ }^{1}$}

Пермский национальный исследовательский политехнический университет (614990, Россия, г. Пермь, Комсомольский пр., 29) ${ }^{1}$ Филиал ООО «ЛУКОЙЛ-Инжиниринг» «ПермНИПИнефть» в г. Перми (614066, Россия, г. Пермь, ул. Советской Армии, 29)

Received / Получена: 06.06.2017. Accepted / Принята: 25.07.2017. Published / Опубликована: 15.09.2017

Key words:

oil displacement coefficient, core, analytical dependence, discriminant analysis, regression analysis, statistical model, oil viscosity, porosity, permeability, irreducible water saturation, rock bulk density, conventional core analysis, clastic deposits, carbonate deposits, regression equation.

\section{Ключевые слова}

коэффициент вытеснения нефти, керн, аналитическая зависимость, дискриминантный анализ, регрессионный анализ, статистическая модель, вязкость нефти, пористость, троницаемость, остаточная водонасыщенность, объемная плотность породы, стандартные исследования керна, терригенные отложения, карбонатные отложения, регрессионное уравнение.

\begin{abstract}
The article is devoted to the problem of evaluation of oil displacement coefficient. Determination of oil displacement coefficient is essential stage for estimation of recoverable reserves, feasibility study of oil recovery factor and control of field development. Complexity of its laboratory determination is caused by labor intensity and duration of a process. When the number of cores is not enough for flow experiments or absent oil recovery factor is evaluated either similarly to neighbor fields or by analytical dependencies that are important to obtain.

During the generalization and analysis of a significant amount of experimental data the authors developed a method for estimation of oil displacement coefficient without its laboratory determination. A proposed method is based on use of data from previous studies to built statistical models for estimation of displacement coefficient using linear step-by-step regression and discriminant analysis.

In order to implement the method along with oil viscosity, knowledge of reservoir parameters such as porosity, permeability, irreducible water saturation and bulk density of a rock, determined by conventional core studies, is required. The main stages of implementation of the method for Visean clastic deposits of the Bashkir arch and Solikamsk depression of the Perm Region are presented. Results of implementation of the method for Bashkir carbonate deposits of the indicated tectonic elements are presented as well. Analysis of initial data allow establishing that there are classes of values for which regression equations are statistically justified. According to the equations model and experimental values of the displacement coefficients are very close to each other. It was concluded based on parameters of the equations that there is abnormal influence of initial oil saturation on the displacement coefficient. It is shown that for reservoirs of low flow characteristics a displacement coefficient is determined by their capacitive properties.
\end{abstract}

Статья посвящена проблеме оценки коэффициента вытеснения нефти, определение которого является обязательным этапом при подсчете извлекаемых запасов, технико-экономическом обосновании коэффициента извлечения нефти и осушествлении контроля разработки месторождений. Сложность его лабораторного определения обусловлена трудоемкостью и длительностью опытов. При недостаточном для фильтрационных экспериментов количестве керна или его полном отсутствии коэффициент вытеснения оценивается либо по аналогии с соседними месторождениями, либо по аналитическим зависимостям, получение которых является актуальной задачей.

В процессе обобщения и анализа значительного объема экспериментальных данных авторами разработан способ оценки коэффициента вытеснения нефти без его лабораторного определения. Предложенный способ основан на использовании данных ранее проведенных исследований для построения статистических моделей оценки коэффициента вытеснения с использованием линейного пошагового регрессионного и дискриминантного анализа. Для реализации способа, наряду с вязкостью нефти, требуется знание фильтрационно-емкостных параметров: пористости, проницаемости, остаточной водонасыщенности, а также объемной плотности породы, определяемых при стандартных исследованиях керна.

В работе приведены основные этапы реализации способа для визейских терригенных отложений месторождений Башкирского свода и Соликамской депрессии Пермского края, а также результаты его применения для башкирских карбонатных отложений указанных тектонических элементов. В процессе анализа исходных данных установлено наличие классов значений, для которых статистически обоснованы регрессионные уравнения, демонстрирующие высокую близость модельных и экспериментальных значений коэффициента вытеснения. По параметрам, входящим в уравнения, сделан вывод об исключительном влиянии начальной нефтенасыщенности на коэффициент вытеснения. Показано, что в коллекторах с низкими фильтрационными характеристиками коэффициент вытеснения определяется их емкостными свойствами.

Evgeniy A. Gladkikh (Author ID in Scopus: 6601914558) - Head of the Laboratory of Modelling of Flow and Enhanced Oil Recovery (tel.: +0073422198544 , e-mail: gladkih.ea@mail.ru). The contact person.

Grigoriy P. Khizhnyak (Author ID in Scopus: 36711848000) - Doctor of Engineering, Associate Professor at the Department of Oil and Gas Technologies (tel: +007 34221982 2, e-mail: xgp@mail.ru).

Vladislav I. Galkin (Author ID in Scopus: 55418067700) - Doctor of Geology and Mineralogy, Professor, Head of the Department of Oil and Gas Geology (tel.: +007 3422198017 , e-mail: vgalkin@psturu).

Nikita A. Popov - Head of the Laboratory for Conventional Studies (tel.: +007 34271701 23, e-mail: Nikita.Popov@pnn.lukoil.com).

Гладких Евгений Александрович - заведующий лабораторией моделирования процессов фильтрации и повышения нефтеотдачи (тел.: +007 3422198544 , Гладких Евгений Александрович - заведующий лаборатор

Хижняк Григорий Петрович - доктор технических наук, доцент кафедры нефтегазовых технологий (тел: +007 34221982 92, e-mail: xgp@mail.ru).

Галкин Владислав Игнатьевич - доктор геолого-минералогических наук, профессор, заведующий кафедрой геологии нефти и газа (тел: +007342 219 80 17, e-mail: vgalkin@pstu.ru).

Попов Никита Андреевич - заведующий лабораторией стандартных исследований (тел.: +007 34271701 23, e-mail: Nikita.Popov@pnn.lukoil.com). 


\section{Introduction}

Determination of oil displacement coefficient is essential stage for estimation of recoverable reserves, feasibility study of oil recovery factor and control of field development. To do that it is necessary to conduct laboratory experiments using real core and formation fluids under conditions that simulate natural deposition [1-6]. That causes labor intensity, complexity and duration of a process. If determination of the displacement coefficient is imposible in laboratory then its value is estimated either by analogy with neighbor deposits [7-9] or by analytical dependences [10-15]. Obtaining of those dependencies is an essential task.

For almost a half a century of research on the displacement coefficient in Perm Region a considerable amount of experimental data has been accumulated, including more than 1100 laboratory experiments for 170 fields and 400 development objects. Such amount of statistical data can represent a basis for development of models for estimation of the displacement coefficient.

The authors propose a method that based on values of parameters determined by conventional core studies and known values of oil viscosity allows estimating a value of the displacement coefficient with high accuracy without its laboratory determination $[16,17]$. The paper presents the main stages of implementation of this method for oil reserves in the Visean terrigenous deposits and results obtained for the carbonate Bashkir deposits of the Bashkir dome fields and the Solikamsk depression. As a result of the method implementation regression equations are statistically proved. Those equations allow to estimate the displacement coefficient.

\section{Geological and physical characteristics of the object of study}

Visean clastic oil and gas bearing complex. The complex is represented by deposits of the Malinovskiy, Tulskiy and Bobrikovskiy formations. The cmplex plays a special role for the oil industry of the Perm Region. More than a half of explored on this teeritory oil reserves are associated with these deposits. Out of 176 developed oil fields (for January $1^{\text {st }} 2015$ ) deposits of Visean oil are explored on 134 fields. There are 46 fields out of them located on the territory of the Bashkir dome and 20 on the Solikamsk depression region. Geological and physical conditions within the Bashkir dome can vary significantly. For example, porosity and gas permeability (from core samples) vary from 0.153 to 0.251 unit fraction and from 0.0245 to $3.19 \mu^{2}$ respectively, oil viscosity differs from 1.87 to $50 \mathrm{mPa} \cdot \mathrm{s}$. The general trend is that the viscosity within the Bashkir dome increases in the direction from north to south and from east to west.

Porosity of the Visean reservoirs varies within the Solikamsk depression from 0.092 to 0.195 fraction and gas permeability from 0.0126 to $0.922 \mu \mathrm{m}^{2}$. Oil is light and low viscousity compared to most of the deposits of the Bashkir dome. It varies from 0.75 to $6.6 \mathrm{mPa} \cdot \mathrm{s}$.

Bashkir carbonate deposits. They are on the second place in terms of hydrocarbon reserves in the territory of the region. Oil deposits are explored in 77 developed deposits, 21 of them are located within the Bashkir dome, 16 are confined to the Solikamsk depression. Porosity of Bashkir reservoirs within dome boundaries varies from 0.124 to 0.226 fraction, gas permeability varies from 0.0214 to $0.576 \mu \mathrm{m}^{2}$. Bashkir oil of the same dome in average is lighter than the Visean one. Viscosity varies from 5.7 to $16.4 \mathrm{mPa} \cdot \mathrm{s}$.

Productive deposits of the Solikamsk depression fields have smaller values of porosity from 0.114 to 0.170 fraction, gas permeability from 0.0062 to $0.180 \mu \mathrm{m}^{2}$ and oil viscosity from 0.88 to $13 \mathrm{mPa} \cdot \mathrm{s}$.

\section{Visean clastic deposits}

\section{Bashkir dome}

Initial sample for Visean clastic deposits was compiled using 71 laboratory measurements of the displacement coefficient (Table 1). The sample encompases 27 fields of the Bashkir dome.

Using these data correlation fields were constructed and correlation coefficients $r$ are determined (see the matrix). 
Table 1

Summary of laboratory measurements of the displacement coefficient

in the Visean clastic deposits of the Bashkir dome

\begin{tabular}{|c|l|c|c|c|c|c|c|c|c|}
\hline No. Field & \multicolumn{1}{|c|}{$\begin{array}{c}K_{\mathrm{p}}, \\
\text { fractions }\end{array}$} & $\begin{array}{c}K_{\mathrm{g} . \text { perm }}, \\
\mu \mathrm{m}^{2}\end{array}$ & $\begin{array}{c}K_{\mathrm{i} . \mathrm{w},} \\
\text { fractions }\end{array}$ & $\begin{array}{c}\rho, \\
\mathrm{g} / \mathrm{cm}^{3}\end{array}$ & $\begin{array}{c}\mu_{\mathrm{o}}, \\
\mathrm{mPa} \cdot \mathrm{s}\end{array}$ & $\begin{array}{c}K_{\mathrm{p} / \rho}, \\
\mathrm{cm}^{3} / \mathrm{g}\end{array}$ & $\begin{array}{c}K_{\text {g.perm }} / \mu_{\mathrm{o}}, \\
\mu \mathrm{m}^{2} /(\mathrm{mPa} \cdot \mathrm{s})\end{array}$ & $\begin{array}{c}K_{\text {disp }}, \\
\text { fractions }\end{array}$ \\
\hline 1 & Byrkinskoe & 0.166 & 0.1130 & 0.226 & 2.16 & 8.40 & 0.0769 & 0.01345 & 0.500 \\
\hline 2 & Trifonovskoe & 0.174 & 0.0245 & 0.461 & 2.17 & 5.37 & 0.0802 & 0.00456 & 0.500 \\
\hline 3 & Kalmiyarskoe & 0.163 & 0.0461 & 0.179 & 2.22 & 8.20 & 0.0734 & 0.00562 & 0.526 \\
\hline 4 & Gondyrevskoe & 0.222 & 0.2058 & 0.100 & 2.06 & 10.30 & 0.1078 & 0.01998 & 0.527 \\
\hline 5 & Yuzhinskoe & 0.189 & 0.1124 & 0.111 & 2.15 & 11.70 & 0.0879 & 0.00961 & 0.528 \\
\hline$\ldots$ & $\ldots$ & $\ldots$ & $\ldots$ & $\ldots$ & $\ldots$ & $\ldots$ & $\ldots$ & $\ldots$ \\
\hline 71 & Krasnoyarsko-Kuedinskoe & 0.229 & 3.1900 & 0.040 & 2.03 & 13.10 & 0.1128 & 0.24351 & 0.720 \\
\hline
\end{tabular}

Correlation matrix for Bashkir dome sample

\begin{tabular}{|c|c|c|c|c|c|c|c|c|}
\hline & $\begin{array}{c}K_{\mathrm{p}}, \\
\text { fractions }\end{array}$ & $\begin{array}{c}K_{\text {g.perm }}, \\
{\mu \mathrm{m}^{2}}^{2}\end{array}$ & $\begin{array}{c}K_{\mathrm{i} . \mathrm{w}}, \\
\text { fractions }\end{array}$ & $\begin{array}{c}\rho, \\
\mathrm{g} / \mathrm{cm}^{3}\end{array}$ & $\begin{array}{c}\mu_{o}, \\
\mathrm{mPa} \cdot \mathrm{s}\end{array}$ & $\begin{array}{c}K_{\mathrm{p} / \mathrm{p}}, \\
\mathrm{cm}^{3} / \mathrm{g}\end{array}$ & $\begin{array}{c}K_{\mathrm{g} \text { perm }} / \mu_{\mathrm{o}} \\
\mu \mathrm{m}^{2} /(\mathrm{mPa} \cdot \mathrm{s})\end{array}$ & $\begin{array}{c}K_{\text {disp }}, \\
\text { fractions }\end{array}$ \\
\hline$K_{\mathrm{p}}$, fractions & 1.00 & $\frac{0.68}{0.000}$ & $\frac{-0.60}{0.000}$ & $\frac{-0.94}{0.000}$ & $\frac{0.37}{0.002}$ & $\frac{0.99}{0.000}$ & $\frac{0.31}{0.009}$ & $\frac{0.58}{0.000}$ \\
\hline$K_{\text {g.perm }}, \mu \mathrm{m}^{2}$ & & 1.00 & $\begin{array}{l}-0.53 \\
0.000 \\
\end{array}$ & $\frac{-0.70}{0.000}$ & $\begin{array}{c}\underline{0.37} \\
\mathbf{0 . 0 0 0} \\
\end{array}$ & $\underline{\underline{0.70}}$ & $\underline{\underline{0.53}}$ & $\begin{array}{r}\underline{0.68} \\
0.000\end{array}$ \\
\hline$K_{\text {i.w }}$, fractions & & & 1.00 & $\frac{0.57}{0.000}$ & $\frac{-0.19}{0.115}$ & $\frac{-0.60}{0.000}$ & $\frac{-0.40}{0.001}$ & $\frac{-0.68}{0.000}$ \\
\hline$\rho, \mathrm{g} / \mathrm{cm}^{3}$ & & & & 1.00 & $\frac{-0.36}{0.000}$ & $\frac{-0.96}{0.000}$ & $\frac{-0.35}{0.003}$ & $\frac{-0.58}{0.000}$ \\
\hline$\mu_{\mathrm{o}}, \mathrm{mPa} \cdot \mathrm{s}$ & & & & & 1.00 & $\begin{array}{r}0.38 \\
0.001\end{array}$ & $\frac{-0.36}{0.002}$ & $\frac{-0.05}{0.683}$ \\
\hline$K_{\mathrm{p} / \rho}, \mathrm{cm}^{3} / \mathrm{g}$ & & & & & & 1.00 & $\frac{0.32}{0.007}$ & $\frac{0.59}{0.000}$ \\
\hline$\left.K_{\text {g.perm }} / \mu_{\mathrm{o}}, \mu \mathrm{m}^{2} /(\mathrm{mPa} \cdot \mathrm{s})\right)$ & & & & & & & 1.00 & $\frac{0.66}{0.000}$ \\
\hline$K_{\text {disp }}$, fractions & & & & & & & & 1.00 \\
\hline
\end{tabular}

Note: a numerator in the cells represents a value of correlation coefficient, a denominator represents a level of statistical significance (p); bold means statistically significant correlation coefficients for which $p<0.05$.

The correlation matrix shows that almost all the studied parameters correlate well with each other. Neverthelles, there are two pairs of links that have no significant connection. Those pairs are viscosity of oil and irreducible water saturation, viscosity of oil and $K_{\text {disp. }}$.

According to the data of the sample performed by the method of stepwise regression analysis [18-25], a multidimensional equation was constructed to estimate model values of the displacement coefficient:

$$
\begin{gathered}
K_{\text {disp }}^{\mathrm{m}}=0,6056+0,0265 K_{\text {g.perm }}- \\
-0,3229 K_{\text {i.w }}+0,1921 \frac{K_{\text {g.perm }}}{\mu_{\mathrm{o}}}
\end{gathered}
$$

when $R^{2}=0.69, p<10^{-5}, N=71$, where $R^{2}$ is a coefficient of determination; $N$ is sample volume.

An order of the parameters in the regression equation determines a degree of their influence on the displacement coefficient. For example, value $K_{\text {disp }}^{\mathrm{m}}$ in the equation (1) is formed firstly under the influence of rock gas permeability and then by values of residual water saturation and a ratio $K_{\text {g.perm }} / \mu_{0}$.

Model and experimental values of $K_{\text {disp }}$ are compared in the Fig. 1.

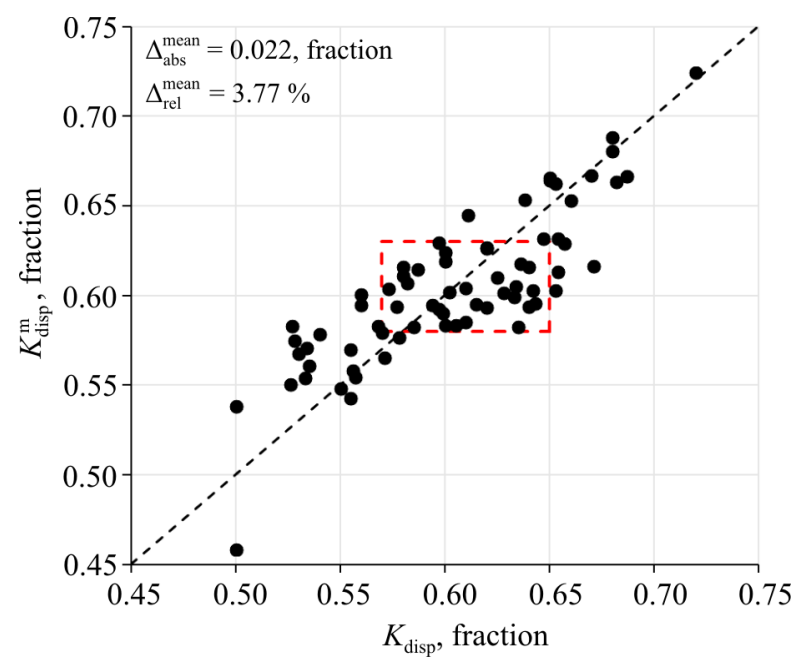

Fig. 1. Correlation field of model and experimental values $K_{\text {disp }}$ 
There are three ranges of values can be distinguished on the Fig. 1 such as:

1) model values of $K_{\text {disp }}$ exceed experimental to the left of the red rectangle;

2) model values of $K_{\text {disp }}$ are below experimental to the right of the red rectangle;

3) model and real values of $K_{\text {disp }}$ do not have strong correlation between in the red rectangle. Similar results were obtained in [26] during processing a sample of a smaller volume. Hence, it can be assumed that a displacement coefficient value for the selected groups is affected by various indicators.

In order to confirm this assumption correlation dependencies of reservoir characteristics are studied in detail. For example, it is possible to determine from the dependence of the mobility coefficient $\left(K_{\mathrm{mob}}=K_{\mathrm{g} . \text { perm }} / \mu_{\mathrm{o}}\right)$ from viscosity (Fig. 2$)$ that there are three groups of values such as:

1) within the interval of values $K_{\mathrm{mob}}$ from the maximum value 0.353 to $0.123 \mu \mathrm{m}^{2} / \mathrm{mPa}$ 's where $K_{\text {mob }}$ changes most intensively if viscosity is increased;

2) within the interval of values $K_{\text {mob }}$ that correspond to change of $\mu_{\mathrm{o}}$ from 17.7 to $0 \mathrm{mPa} \cdot \mathrm{s}$ where values of $K_{\mathrm{mob}}$ change slightly if the viscosity is increased;

3) link between the change in $K_{\operatorname{mob}}$ and $\mu_{\mathrm{o}}$ is weak or null.

Values dedicated to selected groups have also not so ctrong relationship in the coordinates "permeability - mobility coefficient" (Fig. 3).

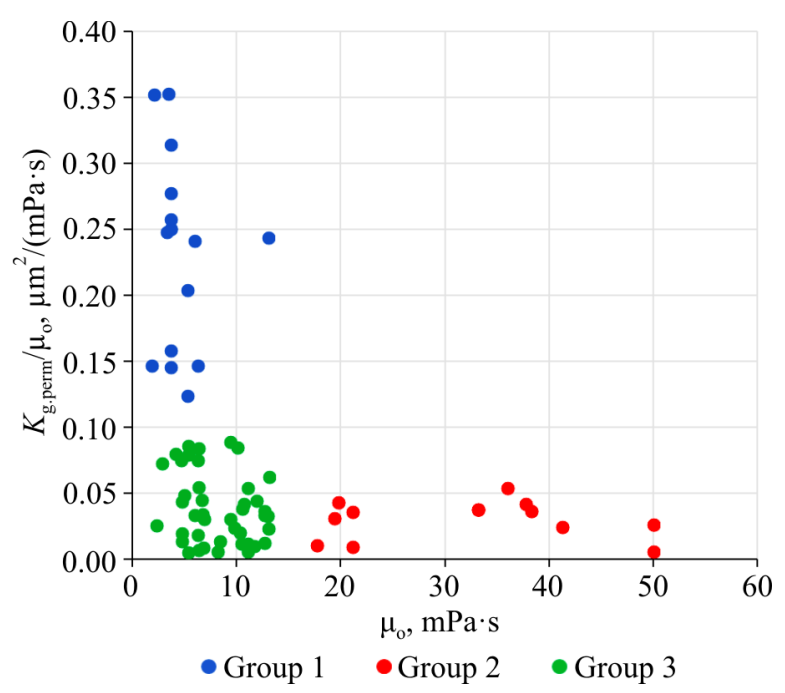

Fig. 2. Change in a mobility coefficient depending on oil viscosity

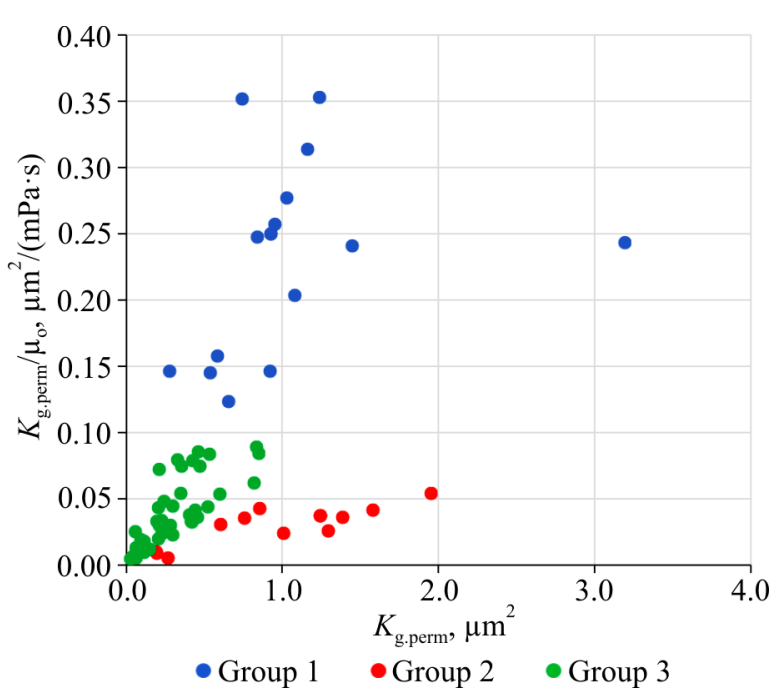

Fig. 3. Dependence of a mobility coefficient on permeability

In order to estimate an oil displacement coefficient using stepwise regression analysis multidimensional equations for selected groups (classes) are obtained:

- for the $1^{\text {st }}$ class

$$
\begin{gathered}
K_{\text {disp }}^{\mathrm{m} 1}=0.5883-0.3541 K_{\text {i.w }}+ \\
+0.0291 K_{\text {g.perm }}+0.2358 \frac{K_{\text {g.perm }}}{\mu_{\mathrm{o}}}
\end{gathered}
$$

when $R^{2}=0.82, p<10^{-4}, N=16$;

- for the $2^{\text {nd }}$ class

$$
\begin{gathered}
K_{\text {disp }}^{\mathrm{m} 2}=-0.5486-0.7384 K_{\text {i.w }}+ \\
+1.9497 K_{\mathrm{p}}+0.3784 \rho
\end{gathered}
$$

when $R^{2}=0.85, p<3.4 \cdot 10^{-4}, N=13$;

- for the $3^{\text {rd }}$ class

$$
\begin{aligned}
K_{\text {disp }}^{\mathrm{m} 3} & =0.8217+0.9362 \frac{K_{\text {g.perm }}}{\mu_{\mathrm{o}}}- \\
& -0.1975 K_{\text {i.w }}-0.1161 \rho
\end{aligned}
$$

when $R^{2}=0.65, p<10^{-5}, N=42$.

Values of $p<0.05$ indicate statistical significance of the equations obtained.

Model values calculated by the equations (2)(4) and experimental ones $K_{\text {disp }}$ are quite close to the line of equal values (see Fig. 4). Correlation coefficients $r$ are equal to 0.91 and 0.93 when $p<10^{-5}$ in both cases. The correlation field of the third class values, when $K_{\text {disp }}<0.6$, in general is 


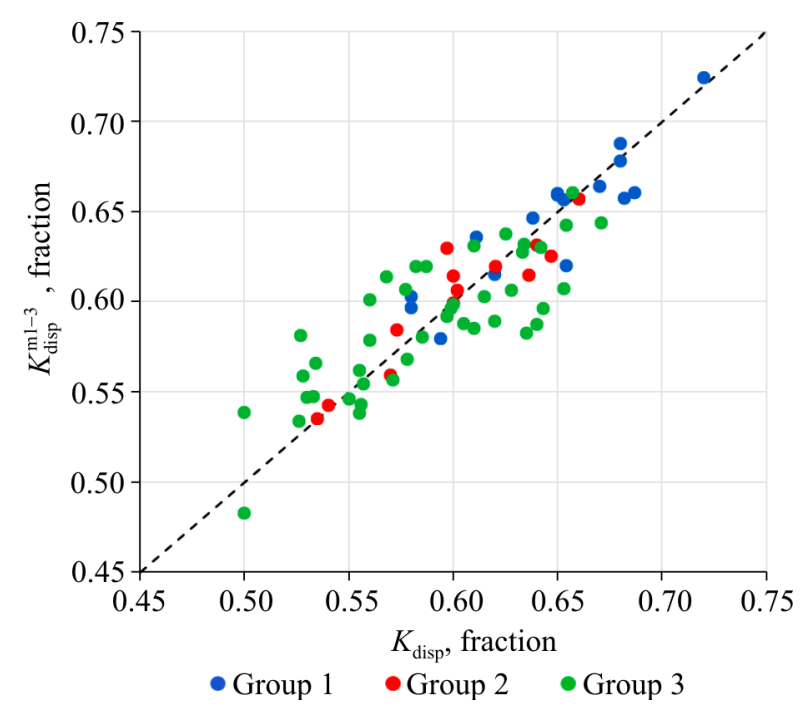

Fig. 4. Correlation field of model and experimental values of $K_{\text {disp }}$ for the three classes

higher than the line of equal values, i.e. migrated towards model ones. When $K_{\text {disp }}>0.6$ it is migrated towards experimental ones. From that it can be assumed that the sample for the third class unites two groups of values with a border between them around $K_{\text {disp }}=0.6$. Therefore, a stepwise regression analysis was performed with construction of equations first for three values $(N=3)$, then for four $(N=4)$ and so on untill $N=42$ (Table 2). That allowed to trace in dynamics the influence of parameters on the displacement coefficient.

There is in the obtained regression equations of up to $N=20\left(K_{\text {disp }}<0.6\right)$ a capacitive parameter "irreducible water saturation $K_{\text {disp }}$ " is on the first place. That parameter then is replaced by flow parameters such as $K_{\text {g.perm }} / \mu_{\mathrm{o}}$, i.e. different parameters in groups influence $K_{\text {disp. }}$. That is confirmed by the values of regression coefficients for parameters in the equations. For example, depending on $K_{\text {disp }}$ values of coeficients of $K_{\text {disp }}$ and $\mu_{\mathrm{o}}$ have extremes in the area $K_{\text {disp }}=0.61$ (Fig. 5).

Table 2

Multidimensional equations of stepwise regression analysis of the $3^{\text {rd }}$ class data of Vesean clastic deposits of Bashkir dome

\begin{tabular}{|c|c|c|}
\hline No. & Equation & Coefficient \\
\hline 3 & $K_{\text {disp }}^{\mathrm{m}}=-0.4985+0.4613 \rho$ & $\begin{array}{l}R^{2}=0.98 \\
p<0.099\end{array}$ \\
\hline 4 & $K_{\text {disp }}^{\mathrm{m}}=0.5314-0.0753 K_{\mathrm{i} . \mathrm{w}}$ & $\begin{array}{l}R^{2}=0.58 \\
p<0.236\end{array}$ \\
\hline 5 & $K_{\text {disp }}^{\mathrm{m}}=0.5337-0.0813 K_{\text {i.w }}$ & $\begin{array}{l}R^{2}=0.65 \\
p<0.101\end{array}$ \\
\hline$\ldots$ & & $\ldots$ \\
\hline 41 & $\begin{array}{l}K_{\text {disp }}^{\mathrm{m}}=0.9070-0.0628 \frac{K_{\text {g.perm }}}{\mu_{\mathrm{o}}}- \\
-0.2721 K_{\mathrm{i} . \mathrm{w}}-0.1262 \rho-0.0060 \mu_{\mathrm{o}}\end{array}$ & $\begin{array}{c}R^{2}=0.67 \\
p<10^{-5}\end{array}$ \\
\hline 42 & $\begin{array}{l}K_{\text {disp }}^{\mathrm{m}}=0.8217-0.9362 \frac{K_{\text {g.perm }}}{\mu_{\mathrm{o}}}- \\
-0.1975 K_{\mathrm{i} . \mathrm{w}}-0.1161 \rho\end{array}$ & $\begin{aligned} R^{2} & =0.65 \\
p & <10^{-5}\end{aligned}$ \\
\hline
\end{tabular}

There is an extremum on the graph at $K_{\text {disp }}=0.60$ for the dependence of determination coefficient $R^{2}$ on displacement coefficient (Fig. 6). It means that up to this value approximation reliability increases and then decreases after. That proves that parameters works well at the left part of the graph and less in the right part.

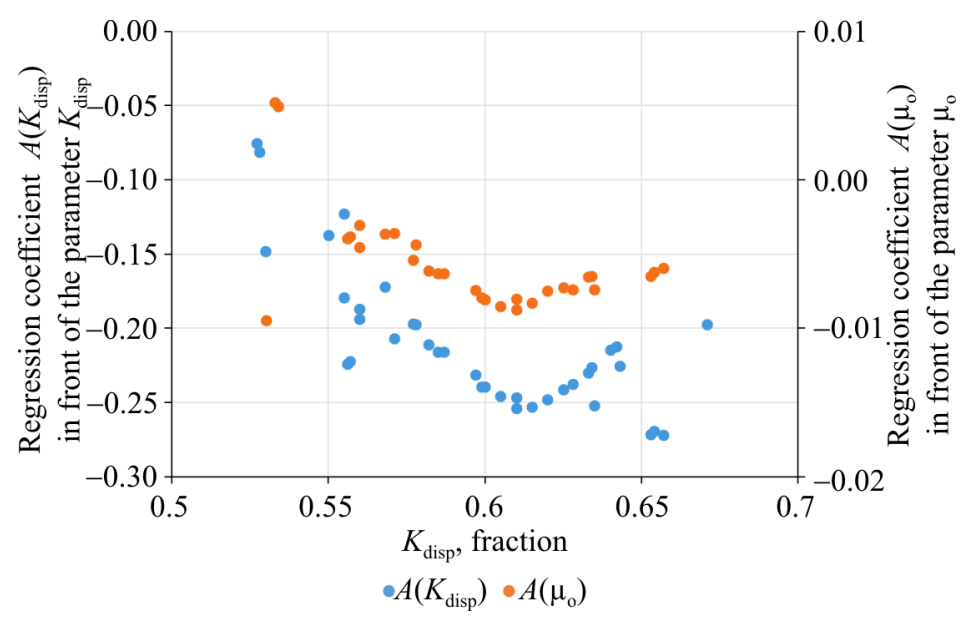

Fig. 5. Dependences of the coefficients of $K_{\text {i.w }}$ and $\mu_{\mathrm{o}}$ on $K_{\text {disp }}$ in the equations during stepwise regression analysis for Visean clastic deposits of the Bashkir dome 
Values of $R^{2}$ that were close to 1 were not considered because they correspond to equations built by a minimum amount of data. An extremum in the area $K_{\text {disp }}=0.55$ can be explained by a local change in parameters of equations and enaibling of parameter "bulk density of rock $\rho$ ".

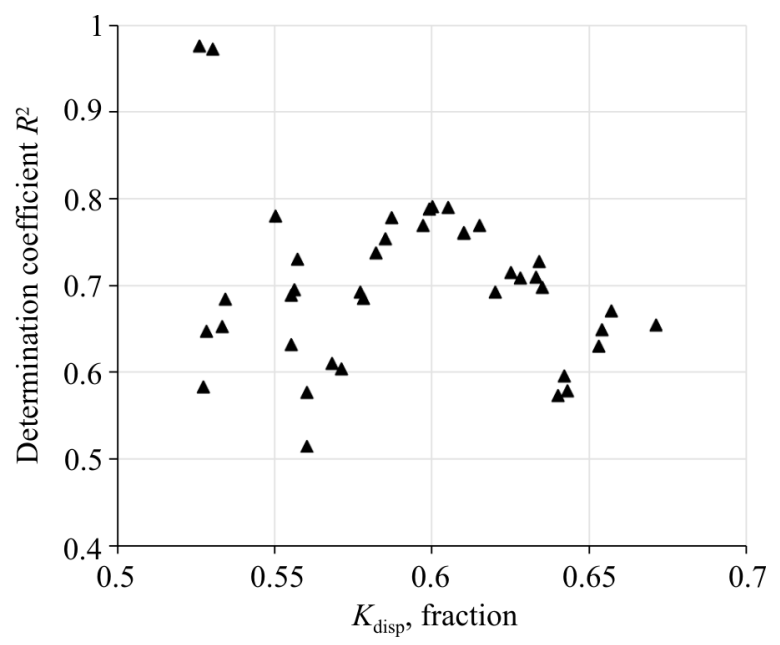

Fig. 6. Dependence of a determination coefficient on $K_{\text {disp }}$ for stepwise regression analysis for Visean clastic deposits of the Bashkir dome

Based on the analysis performed it was established that the sample of the third class includes two subclasses with a relative boundary between them in the region of $K_{\text {disp }}=0.6$, which $R^{2}$ corresponds to. Data belonging to the first or second subclass is determined more precisely by linear discriminant analysis (LDA) [27-29]. The linear discriminant function (LDF) that divides the sample according to the values of a mobility coefficient, irreducible water saturation and density is

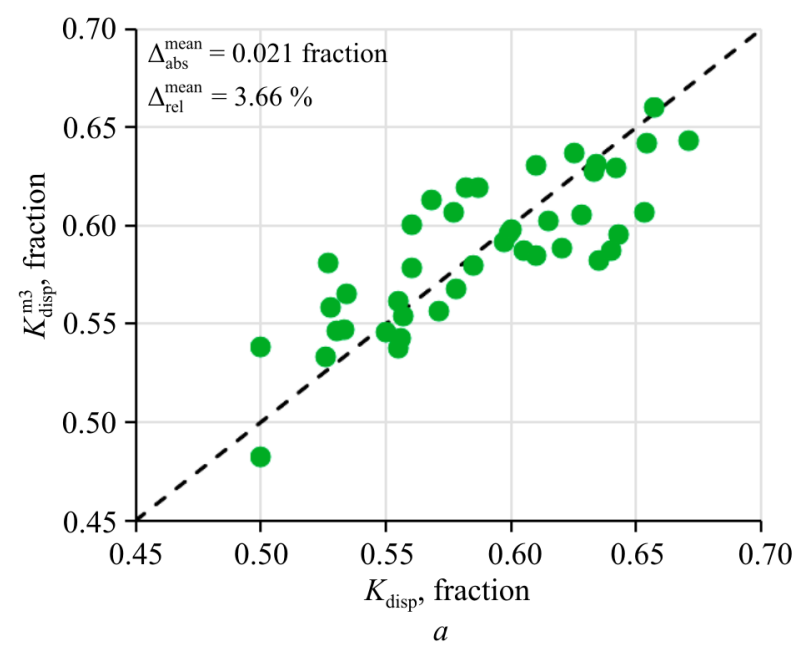

Subclass 1

$$
\begin{aligned}
Z= & -15.5681+91.7717 \frac{K_{\text {g.perm }}}{\mu_{\mathrm{o}}}+ \\
& +6.3586 K_{\text {i.w }}+5.3255 \rho
\end{aligned}
$$

when $R^{2}=0.79, p<10^{-5}$. For values of $Z<1.2$ data belong to the first subclass and to the cesond subclass if values bigger than 1.2.

For selected subclasses following regression coefficients are obtained for evaluation of $K_{\text {disp: }}$ :

- for the $1^{\text {st }}$ subclass of the $3^{\text {rd }}$ class

$$
K_{\text {disp }}^{\mathrm{m} 3-1}=0.5501-0.1500 K_{\text {i.w }}+1.7990 \frac{K_{\text {g.perm }}}{\mu_{\text {o }}}
$$

when $R^{2}=0.62, p<10^{-5}, N=31$;

- for the $2^{\text {nd }}$ subclass of the $3^{\text {rd }}$ class

$$
K_{\text {disp }}^{\mathrm{m} 3-2}=0.5214+2.0426 \frac{K_{\text {g.perm }}}{\mu_{\mathrm{o}}}-0,6285 K_{\text {i.w }}
$$

when $R^{2}=0.77, p<5.18 \cdot 10^{-3}, N=11$.

Equations (6) and (7) include some parameters, but differ in the values of the regression coefficients.

As a result of subclasses allocation the correlation field is uniformly distributed along a line of equal values (Fig. $7 b$ ) and consists of three areas (if $K_{\text {disp }}<0.57$ that is the area of $1^{\text {st }}$ subclass values; if $K_{\text {disp }}>0.63$ that is the area of $2^{\text {nd }}$ subclass; if $0.57<K_{\text {disp }}<0.63$ that is transition area from the $1^{\text {st }}$ to the $2^{\text {nd }}$ subclasses), that transit smoothly to each other. Accuracy of model values $K_{\text {disp }}$ estimation for the third class generally has increased in comparison with a case that has no subclasses allocation (Fig. 7a).

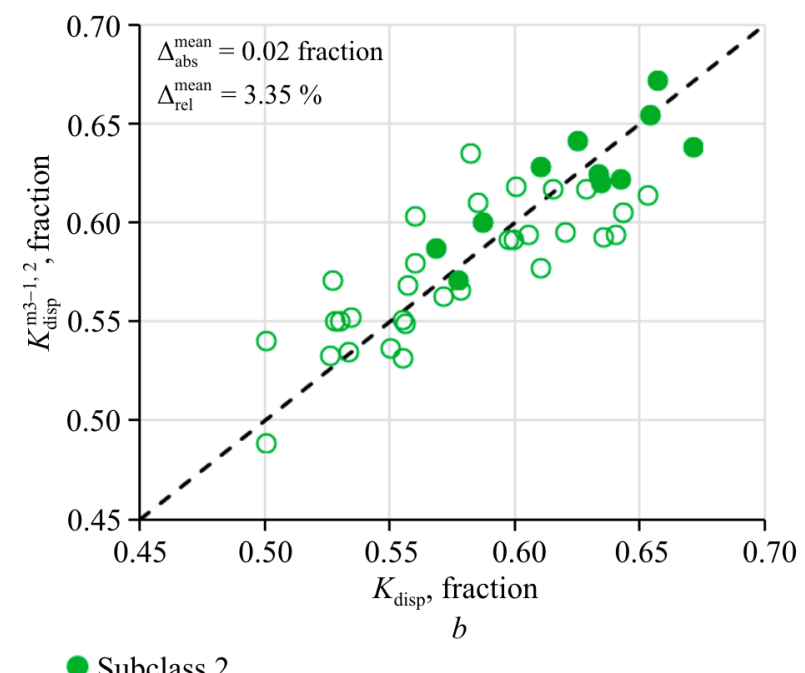

Subclass 2

Fig. 7. Comparison of model and experimental values of $\mathrm{K}_{\mathrm{disp}}$ for the $3^{\text {rd }}$ class before $(a)$ and after $(b)$ the allocation of subclasses 
Thus, the sample for Visean deposits of Bashkir dome fields was described by four regression equations (2), (3), (6) and (7), which reduced the relative error in estimation of model values of $K_{\text {disp }}$ (Fig. 8).

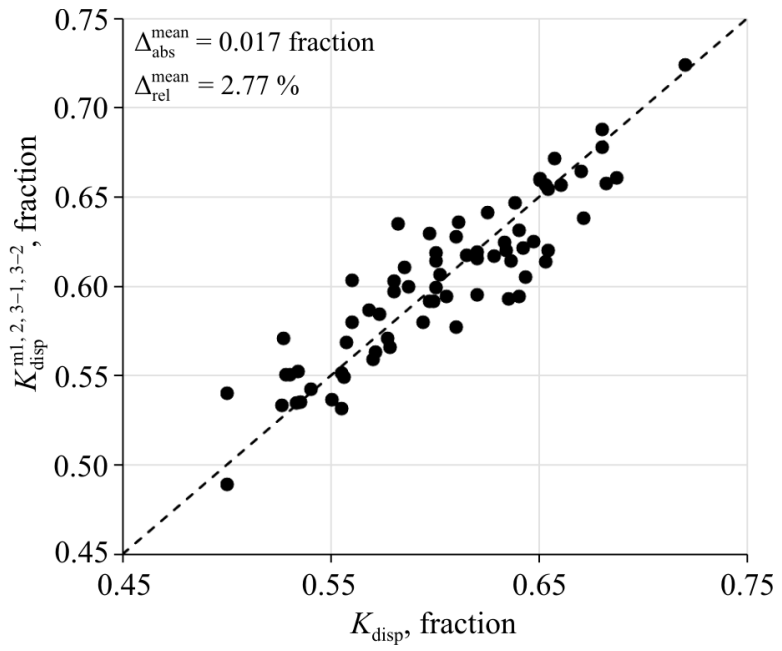

Fig. 8. Comparison of the model and experimental values of $\mathrm{K}_{\text {disp }}$ after the selection of classes and subclasses in the initial sample for Visean clastic deposits of Bashkir dome fields

\section{Solikamsk depression}

Initial sample for clastic deposits of the Visean age of Solikamsk depression fields, considered in [30], was extended to 46 measurements of $K_{\text {disp. }}$.

Based on the sample data correlation fields are constructed and correlation coefficients $r$ are determined (see matrix).
The correlation matrix shows that all the parameters studied correlate well with each other except for oil viscosity. A multidimensional regression equation was obtained for the entire sample.

$$
K_{\text {disp }}^{\mathrm{m}}=0.6978-0.4725 K_{\mathrm{i} . \mathrm{w}}+0.0943 \frac{K_{\mathrm{g} . \text { perm }}}{\mu_{\mathrm{o}}}
$$

when $R^{2}=0.69, p<10^{-4}, N=46$.

Comparison of values calculated from equation (8) and experimental values of $K_{\text {disp }}$ (Fig. 9) showed that the correlation field at $K_{\text {disp }}<0.62$ (to the left of the red line) has a larger scatter of values compared to the right-hand side of the field, where model values of $K_{\text {disp }}$ are substantially lower than experimental ones.

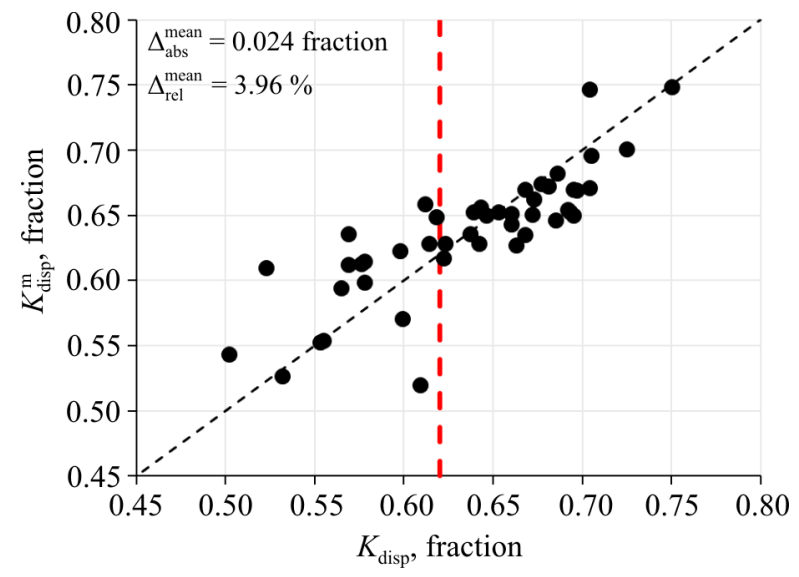

Fig. 9. Correlation field of model and experimental values of $\mathrm{K}_{\text {disp }}$ in Visean clastic deposits of Solikamsk depression fields

Correlation matrix for Solikamsk depression sample

\begin{tabular}{|c|c|c|c|c|c|c|c|c|}
\hline & $\begin{array}{c}K_{\mathrm{p}}, \\
\text { fractions }\end{array}$ & $\begin{array}{c}K_{\text {g.perm }} \\
\mu \mathrm{m}^{2}\end{array}$ & $\begin{array}{c}K_{\text {i.w }}, \\
\text { fractions }\end{array}$ & $\begin{array}{c}\rho, \\
g / \mathrm{cm}^{3}\end{array}$ & $\begin{array}{c}\mu_{\mathrm{o}}, \\
\mathrm{mPa} \cdot \mathrm{s}\end{array}$ & $\begin{array}{l}K_{\mathrm{p} / \rho}, \\
\mathrm{cm}^{3} / \mathrm{g}\end{array}$ & $\begin{array}{c}K_{\text {g.perm }} / \mu_{\mathrm{o}} \\
\mu \mathrm{m}^{2} /(\mathrm{mPa} \cdot \mathrm{s})\end{array}$ & $\begin{array}{c}K_{\text {disp }} \\
\text { fractions }\end{array}$ \\
\hline$K_{\mathrm{p}}$, fractions & 1.00 & $\frac{0.81}{0.000}$ & $\frac{-0.66}{0.000}$ & $\frac{-0.96}{0.000}$ & $\frac{0.04}{0.776}$ & $\frac{0.99}{0.000}$ & $\frac{0.67}{0.000}$ & $\frac{0.65}{0.000}$ \\
\hline$K_{\mathrm{g} . \mathrm{perm}}, \mu \mathrm{m}^{2}$ & & 1.00 & $\frac{-0.54}{0.000}$ & $\frac{-0.72}{0.000}$ & $\frac{-0.05}{0.766}$ & $\underline{0.82}$ & $\underline{0.91}$ & $\frac{0.61}{0.000}$ \\
\hline$K_{\text {i.w.w }}$, fractions & & & 1.00 & $\frac{0.69}{0.000}$ & $\frac{-0.20}{0.184}$ & $\frac{-0.66}{0.000}$ & $\frac{-0.42}{0.004}$ & $\frac{-0.76}{0.000}$ \\
\hline$\rho, \mathrm{g} / \mathrm{cm}^{3}$ & & & & 1.00 & $\begin{array}{l}-0.01 \\
0.926\end{array}$ & $\frac{-0.96}{0.000}$ & $\frac{-0.60}{0.003}$ & $\begin{array}{l}-\frac{-0.61}{0.000} \\
\end{array}$ \\
\hline$\mu_{o}, \mathrm{mPa} \cdot \mathrm{s}$ & & & & & 1.00 & $\frac{0.03}{0.834}$ & $\frac{-0.28}{0.058}$ & $\begin{array}{l}-0.04 \\
0.792 \\
\end{array}$ \\
\hline$K_{\mathrm{p} / \rho}, \mathrm{cm}^{3} / \mathrm{g}$ & & & & & & 1.00 & $\frac{0.68}{0.007}$ & $\frac{0.66}{0.000}$ \\
\hline $\begin{array}{l}K_{\text {g.perm }} / \mu_{\mathrm{o}} \\
\mu \mathrm{m}^{2} /(\mathrm{mPa} \cdot \mathrm{s})\end{array}$ & & & & & & & 1.00 & $\frac{0.55}{0.000}$ \\
\hline $\bar{K}_{\text {disp }}$, fractions & & & & & & & & 1.00 \\
\hline
\end{tabular}


Similarly to Visean clastic deposits of the Bashkir dome, it can be assumed that the $K_{\text {disp }}$ in the left and right parts of the correlation field relative to the red line is influenced by various parameters.

That is confirmed by a dependence of the determination coefficient $R^{2}$ on $K_{\text {disp }}$ (Fig. 10), obtained by stepwise regression analysis with the construction of equations first for $N=3$ sample values, then for $N=4$ and so on until $N=46$. This dependence tends to decrease to $K_{\text {disp }}=0.62$, and increase after inflection and then divides the sample into two classes.

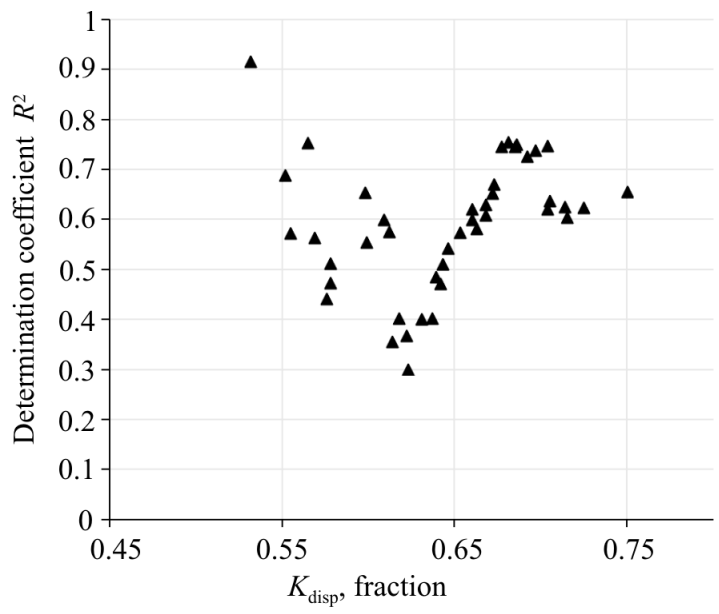

Fig. 10. Dependence of determination coefficient on $K_{\text {disp }}$ in stepwide regression analysis for Visean clastic deposits of Solikamsk depression fields

In order to determine the class LDA is used. The discriminant function $Z$, which divides the sample into two classes looks like

$$
\begin{gathered}
Z=-56.7220+132.0232 K_{\mathrm{p}}- \\
-13.2649 K_{\text {i.w }}-5.3172 K_{\text {g.perm }}+17.8673 \rho
\end{gathered}
$$

when $R^{2}=0.77, p<10^{-5}, N=46$.

Having $Z<-0.5$ data belong to the first class, and to the $2^{\text {nd }}$ if $Z>-0.5$. After two classes in the the initial sample were selected linear regression equations for them were obtained:

- for the $1^{\text {st }}$ class

$$
\begin{aligned}
& K_{\text {disp }}^{\mathrm{m} 1}=-0.5483-0.2514 K_{\mathrm{i} . \mathrm{w}}+0.4811 \rho+ \\
& +2.6959 \frac{K_{\text {g.perm }}}{\mu_{\mathrm{o}}}-1.1552 K_{\text {g.perm }}+0.0159 \mu_{\mathrm{o}}
\end{aligned}
$$

when $R^{2}=0.79, p<1.94 \cdot 10^{-3}, N=18$;

- for the $2^{\text {nd }}$ class

$$
\begin{gathered}
K_{\text {disp }}^{\mathrm{m} 2}=0.7885-0.0759 \frac{K_{\text {g.perm }}}{\mu_{\mathrm{o}}}- \\
-0.7088 K_{\text {i.w }}-0.0203 \mu_{\mathrm{o}}+0.0671 K_{\text {g.perm }}
\end{gathered}
$$

when $R^{2}=0.84, p<10^{-5}, N=28$.
Comparison of model and experimental values of $K_{\text {disp }}$ (Fig. 11) showed that they control each other quite well $(R=0.93)$. At the same time, model values of the displacement coefficient now can be estimated with less error in comparison with the case where no classes are selected.

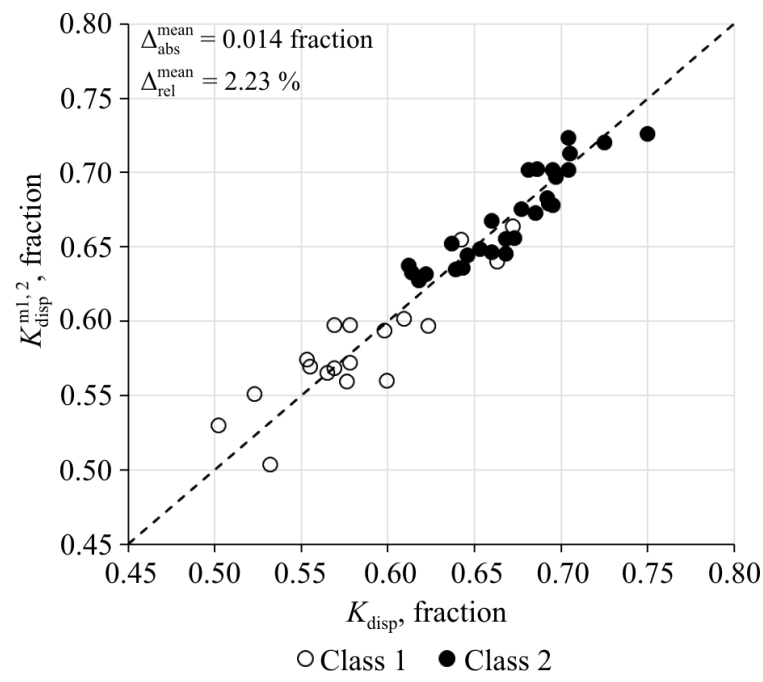

Fig. 11. Comparison of experimental and model values of $K_{\text {disp }}$ for two classes of Visean clastic deposits of Solikamsk depression fields

\section{Carbonate Bashkir deposits}

Using the mentioned approach, data for Bashkir carbonate deposits of Bashkir dome fields and Solikamsk depression were analyzed.

In order to classify data from the Bashkir dome LDF is obtained:

$$
\begin{aligned}
Z & =96.2606+48.8722 K_{\text {i.w }}- \\
& -41.1925 \rho-78.8568 K_{\mathrm{p}}
\end{aligned}
$$

when $R^{2}=0.77$ and $p<3 \cdot 10^{-5}$.

When $Z>0$ data belong to the $1^{\text {st }}$ class and when $Z<0$ it belong to the $2^{\text {nd }}$ one.

A displacement coefficient in the productive Bashkir deposits of the Bashkir dome is estimated by equations with high values of the determination coefficient, that are as follows:

- for the $1^{\text {st }}$ class

$$
\begin{gathered}
K_{\text {disp }}^{\mathrm{m} 1}=6.2282-0.5105 K_{\text {i.w }}+ \\
+0.0122 \mu_{\mathrm{o}}-2.2167 \rho-4.3314 K_{\mathrm{p}}
\end{gathered}
$$

when $R^{2}=0.98, p<0,0014$;

- for the $2^{\text {nd }}$ class

$$
\begin{gathered}
K_{\text {disp }}^{\mathrm{m} 2}=1.9903-0.0076 \mu_{\mathrm{o}}+ \\
+0.1579 K_{\text {g.perm }}-1.4349 K_{\mathrm{p}}-0.4935 \rho
\end{gathered}
$$

when $R^{2}=0.95, p<0.0021$. 
Comparison of experimental values and values calculated in accordance with equations (13) and (14) of the $K_{\text {disp }}$ (Fig. 12b) shows, that they control each other quite well $(r=0.99)$. At the same time, mean relative error in the estimation of $K_{\text {disp }}$ decreased in 3.7 times in comparison with the case where no classes were allocated (Fig. 12a). The equations obtained in this paper approximate the sample better than in [31].

Equations for two classes of Bashkir Carbonate deposits of Solikamsk depression fields are obtained in the same way:

- for the $1^{\text {st }}$ class

$$
\begin{aligned}
& K_{\text {disp }}^{\mathrm{m} 1}=1.1483-5.6251 K_{\text {g.perm }}+0.1718 \mu_{\mathrm{o}}+ \\
& +16.1795 \frac{K_{\text {g.perm }}}{\mu_{\mathrm{o}}}-0.4404 \rho-0.1534 K_{\text {i.w }}
\end{aligned}
$$

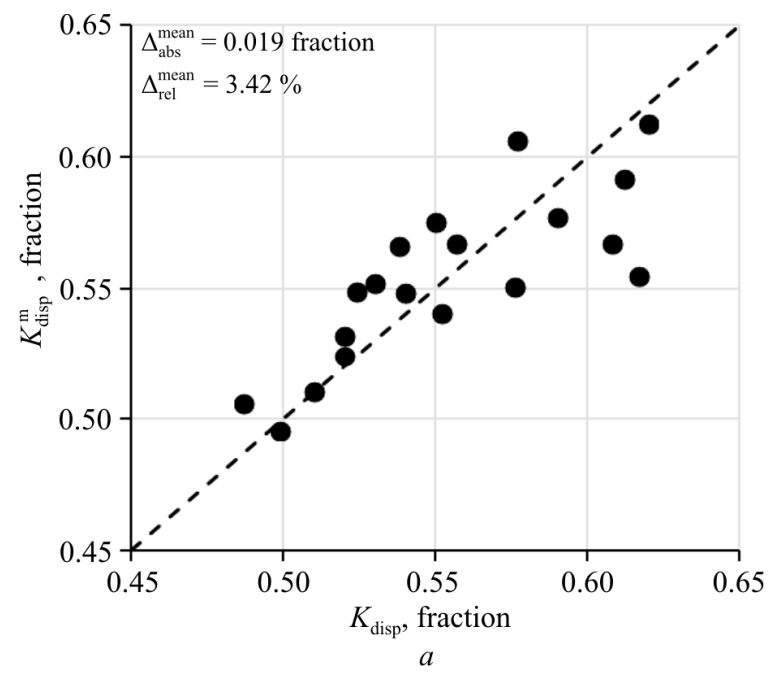

when $R^{2}=0.99, p<0.0026$;

- for the $2^{\text {nd }}$ class

$K_{\text {disp }}^{\mathrm{m} 2}=0.5712+0.1914 K_{\text {g.perm }}+0.2823 \frac{K_{\text {g.perm }}}{\mu_{\mathrm{o}}}(16)$

when $R^{2}=0.40, p<0.077$.

At that, the first class includes data for which the value of the discriminant function (17) is greater than 0.5 and $Z<0.5$ for the second one:

$$
\begin{gathered}
Z=101.442-191.381 K_{\mathrm{p}}+ \\
+29.490 K_{\mathrm{i} . \mathrm{w}}+13.620 K_{\mathrm{g} \text {.perm }}-35.118 \rho
\end{gathered}
$$

when $R^{2}=0.84, p<7 \cdot 10^{-6}$.

Model values of $K_{\text {disp }}$ calculaterd using equations (15), (16) correlate with experimental ones quite good (Fig. 13).

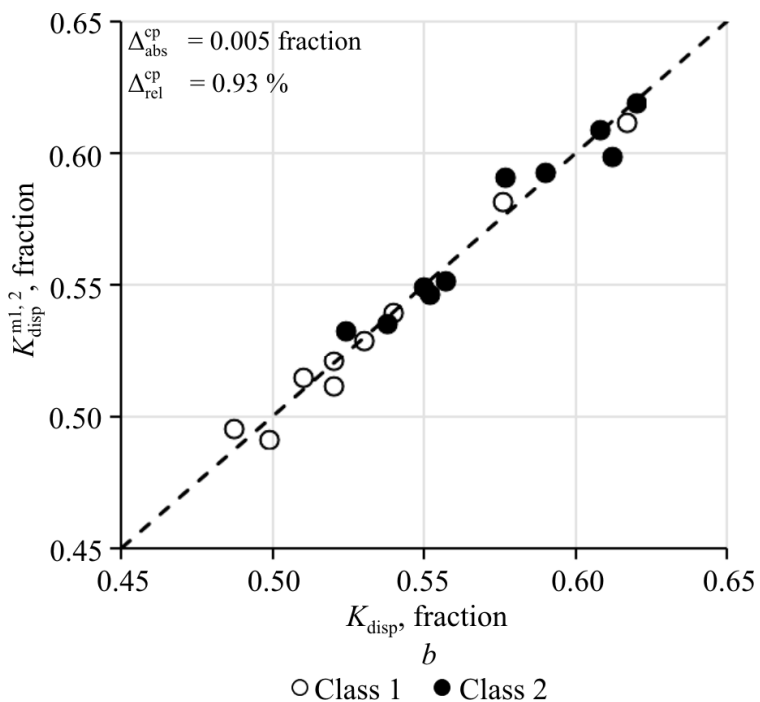

Fig. 12. Comparison of experimental and model values of a displacement coefficient before $(a)$ and after $(b)$ allocation into the classes of a sample of Bashkirian carbonate deposits of Bashkir dome fields
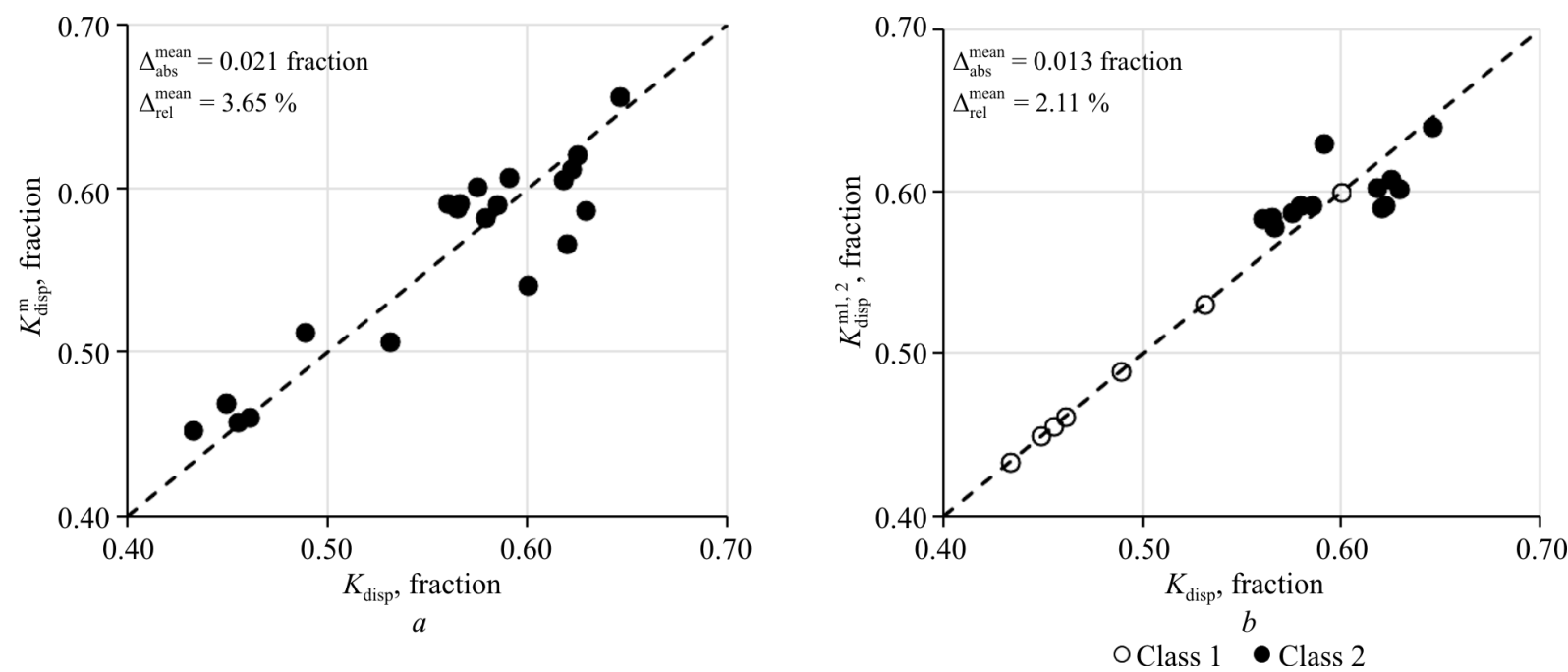

Fig. 13. Comparison of model and experimental values of a displacement coefficient before $(a)$ and after $(b)$ allocation into the classes of a sample of Bashkirian carbonate deposits of Solikamsk depression fields 


\section{Conclusion}

As a result of the performed studies the following conslusions were obtained:

1. A value of oil displacement coefficient in clastic deposits is influenced mainly by the irreducible water saturation or initial oil saturation of the rock.

2. A coefficient of oil displacement in carbonate rocks is formed mainly due to their reservoir properties.
3. The parameter "oil viscosity" takes part in the formation of values of a displacement coefficient both in clastic and carbonate deposits.

4. The proposed method allows estimating a value of the displacement coefficient with no laboratory determination using conventional core studies and oil viscosity data.

\section{References}

1. OST 39-195-86. Neft'. Metod opredeleniia koeffitsienta vytesneniia nefti vodoi $\mathrm{v}$ laboratornykh usloviiakh [Oil. The method of determination of the coefficient of displacement of oil by water in the laboratory]. Moscow, Minnefteprom, 1986, 19 p.

2. Khizhniak G.P., Balueva N.Iu., Mordvinov V.A., Iushkov I.R. Rezul'taty laboratornykh issledovanii po polimernomu vytesneniiu nefti [Results of laboratory studies on polymer displacement of oil]. Vestnik Permskogo gosudarstvennogo tekhnicheskogo universiteta. Geologiia. Neftegazovoe i gornoe delo, 2006, vol.5, no.1, pp.122-125.

3. Khizhniak G.P., Tatarinov I.A., Spasibko A.V. Primenenie biopolimera BP-92 pri laboratornom opredelenii koeffitsienta neftevytesneniia turneiskikh otlozhenii Aptugaiskogo mestorozhdeniia [The use of biopolymer BP-92 in the laboratory determination of the oil displacement coefficient of the Tournaisian deposits of the Aputaisky deposit]. Geologiia, geofizika $i$ razrabotka neftianykh $i$ gazovykh mestorozhdenii, 2007, no.1, pp.50-54.

4. Khizhniak G.P., Liadova N.A. Opredelenie koeffitsienta neftevytesneniia razlichnymi agentami dlia porod-kollektorov Permskogo kraia [Determination of the coefficient of oil displacement by various agents for reservoir rocks in Perm Krai]. Geologiia, geofizika $i$ razrabotka neftianykh i gazovykh mestorozhdenii, 2008, no.9, pp.49-54.

5. Andersen M. A., Duncan B., McLin R. Core truth in formation evaluation. Oilfield Review, 2013, no.2, pp.16-25.

6. Owusu P.A., De Hua L., Nagre R.D. Prognostication of water flooding performance in communicating layered reservoir. International Journal of Earth Sciences and Engineering, 2015, vol.8(5), pp.20042010. DOI: 10.13140/RG.2.1.3413.7360

7. Kerans C., Lucia F.J., Senger R.K. Integrated characterization of carbonate ramp reservoirs using Permian San Andres Formation outcrop analogs. American Association of Petroleum Geologists Bulletin, 1994, no.78, pp.181-216. DOI: 10.1306/BDFF905A-1718-11D7$8645000102 \mathrm{C} 1865 \mathrm{D}$
8. Raspopov A.V., Khizhniak G.P. Obosnovanie koeffitsienta vytesneniia nefti vodoi s privlecheniem rezul'tatov issledovanii ob"ektov-analogov [Substantiation of the coefficient of oil displacement by water with the involvement of the results of research of analogical objects]. Geologiia, geofizika i razrabotka neftianykh $i$ gazovykh mestorozhdenii, 2009, no.6, pp.39-43.

9. Khizhniak G.P. Kompleksnoe reshenie problemy otsenki koeffitsienta vytesneniia nefti $\mathrm{v}$ razlichnykh geologo-tekhnologicheskikh usloviiakh [A comprehensive solution to the problem of estimating the oil displacement coefficient in various geological and technological conditions]. Abstract of Doctor's degree dissertation. Perm', 2012.

10. Tul'bovich B.I., Mikhnevich V.G., Mitrofanov V.P., Beizman V.B., Khizhniak G.P. Primenenie obobshchennykh petrofizicheskikh zavisimostei pri podschete balansovykh i izvlekaemykh zapasov [Application of generalized petrophysical dependencies in the calculation of balance and recoverable reserves]. Problemy geologii i razrabotki neftianykh mestorozhdenii $v$ raionakh $s$ istoshchaiushchimisia resursami: sbornik nauchnykh trudov. Ufa, BashNIPIneft', 1989, iss.79, pp.117-123.

11. Rampersad P.R., Ogbe D.O., Kamath V.A., Islam R. Impact of trapping of residual oil by mobile water on recovery performance in miscible enhanced oil recovery processes. SPE - Proceedings of the SPE Rocky Mountain Regional/Low Permeability Reservoirs Symposium and Exhibition. Denver, 1995, pp.203-213. DOI: $10.2118 / 29563-M S$

12. Khizhniak G.P. Petrofizicheskie issledovaniia dinamicheskikh osobennostei struktury porovogo prostranstva porod-kollektorov $\mathrm{v}$ sviazi s problemami nefteizvlecheniia (na primere zalezhei Permskogo Prikam'ia) [Petrophysical studies of the dynamic features of the pore space structure of reservoir rocks in connection with the problems of oil recovery (on the example of deposits of Perm Kama region)]. Abstract of Ph. D. thesis. Perm', 2000. 
13. Gomes J.S., Ribeiro M.T., Strohmenger C.J., Negahban S., Kalam M.Z. Carbonate reservoir rock typing The link between geology and SCAL. SPE -Proceedings of the 13th Abu Dhabi International Petroleum Exhibition and Conference, ADIPEC 2008. SPE, 2008, vol.3, pp.1643-1656. DOI: 10.2118/118284-MS

14. Khizhniak G.P., Poplaukhina T.B., Galkin S.V., Efimov A.A. Opyt primeneniia metodiki otsenki koeffitsienta neftevytesneniia pri proektirovanii razrabotki neftianykh mestorozhdenii Permskogo kraia [Experience in applying the methodology for estimating the oil displacement coefficient in designing the development of oil deposits in Perm Krai]. Geologiia, geofizika $i$ razrabotka neftianykh $i$ gazovykh mestorozhdenii, 2009, no.8, pp.42-45.

15. Khizhniak G.P., Raspopov A.V., Efimov A.A. Metodicheskie podkhody pri obosnovanii koeffitsienta vytesneniia nefti $\mathrm{v}$ razlichnykh geologo-fizicheskikh usloviiakh [Methodical approaches in substantiating the oil displacement coefficient in various geological and physical conditions]. Geologiia, geofizika i razrabotka neftianykh $i$ gazovykh mestorozhdenii, 2009, no.10, pp.32-35.

16. Galkin V.I., Gladkikh E.A., Khizhniak G.P. Sposob opredeleniia koeffitsienta vytesneniia nefti bashkirskikh karbonatnykh otlozhenii Bashkirskogo svoda [The method for determining the oil displacement coefficient of the Bashkir carbonate deposits of the Bashkir Arch]. Zaiavka № 028257 RF, kl. MPK G01N 15/08, no. 2017116297.

17. Galkin V.I., Gladkikh E.A., Khizhniak G.P. Sposob opredeleniia koeffitsienta vytesneniia nefti bashkirskikh karbonatnykh otlozhenii Solikamskoi depressii [Method for determining the oil displacement coefficient of Bashkir carbonate deposits of the Solikamsk depression]. Zaiavka № 028256 RF, kl. MПK G01N 15/08, no. 2017116296.

18. Johnson N.L., Leone F.C. Statistics and experimental design. New York, London, Sydney, Toronto, 1977, $606 \mathrm{p}$.

19. Montgomery D.C., Peck E.A. Introduction to linear regression analysis. New York, John Wiley \& Sons, 1982, 504 p.

20. Tiab D. Modern core analysis. Vol. 1. Theory, core laboratories. Houston, 1993, 200 p.

21. Jensen J.L., Lake L.W., Corbett P.W.M., Goggin D.J. Statistics for petroleum engineers and geoscientists. Ed. L.W. Lake. New Jersey, Prentice Hall PTR, 1997, 362 p.

22. Houze O., Viturat D., Fjaere O.S. Dinamic data analysis. Paris, Kappa Engineering, 2008, 694 p.

23. Galkin S.V., Poplaukhina T.B., Raspopov A.V., Khizhniak G.P. Otsenka koeffitsientov izvlecheniia nefti dlia mestorozhdenii Permskogo kraia na osnove statisticheskikh modelei [Estimation of oil recovery coefficients for Perm
Krai deposits on the basis of statistical models]. Neftianoe khoziaistvo, 2009, no.4, pp.38-39.

24. Galkin V.I., Khizhniak G.P., Amirov A.M., Gladkikh E.A. Assessment of efficiency of core sample acidizing by means of regression analysis. Bulletin of Perm National Research Polytechnic University. Geology. Oil \& Gas Engineering \& Mining, 2014, no.13, pp.38-48. DOI: 10.15593/2224-9923/2014.13.4

25. Galkin V.I., Ponomareva I.N., Repina V.A. Study of oil recovery from reservoirs of different void types with use of multidimensional statistical analysis. Bulletin of Perm National Research Polytechnic University. Geology. Oil \& Gas Engineering \& Mining, 2016, vol.15, no.19, pp.145-154. DOI: 10.15593/2224-9923/2016.19.5

26. Gladkikh E.A., Galkin V.I., Khizhniak G.P. Ob otsenke koeffitsienta vytesneniia nefti vizeiskikh terrigennykh otlozhenii [On the evaluation of the oil displacement coefficient of Visean terrigenous deposits]. Sovremennye tendentsii razvitiia nauki $i$ tekhnologii. Materialy XXIV Mezhdunarodnoi nauchno-prakticheskoi konferentsii. Belgorod, 2017, no.3-2, pp.62-66.

27. Devis Dzh. Statistika i analiz geologicheskikh dannykh [Statistics and analysis of geological data]. Moscow, Mir, 1977, 353 p.

28. Chumakov G.N. Probabilistic estimate of effectiveness of the method of cyclic bed fluid injection. Bulletin of Perm National Research Polytechnic University. Geology. Oil \& Gas Engineering \& Mining, 2014, no.13, pp.49-58. DOI: 10.15593/2224-9923/2014.13.5

29. Galkin V.I., Ponomareva I.N., Cherepanov S.S. Development of the methodology for evaluation of possibilities to determine reservoir types based on pressure build-up curves, geological and reservoir properties of the formation (case study of famen deposits of Ozernoe field). Bulletin of Perm National Research Polytechnic University. Geology. Oil \& Gas Engineering \& Mining, 2015, no.17, pp.32-40. DOI: 10.15593/2224-9923/2015.17.4

30. Gladkikh E.A., Galkin V.I., Khizhniak G.P. $\mathrm{K}$ voprosu opredeleniia koeffitsienta vytesneniia nefti vodoi dlia vizeiskikh terrigennykh otlozhenii mestorozhdenii Solikamskoi depressii Permskogo kraia [On the determination of the coefficient of oil displacement by water for Visean terrigenous deposits of the Solikamsk depression in the Perm region]. Novaia nauka: istoriia stanovleniia, sovremennoe sostoianie, perspektivy razvitiia. Materialy mezhdunarodnoi nauchnoprakticheskoi konferentsii. Perm', 2017, pp.211-213.

31. Gladkikh E.A., Khizhniak G.P. Razrabotka modeli dlia otsenki koeffitsienta vytesneniia nefti (na primere bashkirskikh karbonatnykh otlozhenii) [Development of a model for estimating the oil displacement coefficient (using the example of Bashkir carbonate deposits)]. Neftepromyslovoe delo, 2017, no.5, pp.9-14. 


\section{Библиографический список}

1. ОСТ 39-195-86. Нефть. Метод определения коэффициента вытеснения нефти водой в лабораторных условиях. - М.: Миннефтепром, 1986. - 19 c.

2. Результаты лабораторных исследований по полимерному вытеснению нефти / Г.П. Хижняк, Н.Ю. Балуева, В.А. Мордвинов, И.Р. Юшков // Вестник Пермского государственного технического университета. Геология. Нефтегазовое и горное дело. 2006. - Т. 5, № 1. - С. 122-125.

3. Хижняк Г.П., Татаринов И.А., Спасибко А.В. Применение биополимера БП-92 при лабораторном определении коэффициента нефтевытеснения турнейских отложений Аптугайского месторождения // Геология, геофизика и разработка нефтяных и газовых месторождений. - 2007. - № 1. - С. 50-54.

4. Хижняк Г.П., Лядова Н.А. Определение коэффициента нефтевытеснения различными агентами для пород-коллекторов Пермского края // Геология, геофизика и разработка нефтяных и газовых месторождений. - 2008. - № 9. - С. 49-54.

5. Andersen M.A., Duncan B., McLin R. Core truth in formation evaluation // Oilfield Review. - 2013. - № 2. P. 16-25.

6. Owusu P.A., De Hua L., Nagre R.D. Prognostication of water flooding performance in communicating layered reservoir // International Journal of Earth Sciences and Engineering. - 2015. - Vol. 8(5). - P. 2004-2010. DOI: 10.13140/RG.2.1.3413.7360

7. Kerans C., Lucia F.J., Senger R.K. Integrated characterization of carbonate ramp reservoirs using Permian San Andres Formation outcrop analogs // American Association of Petroleum Geologists Bulletin. 1994. - № 78. - P. 181-216. DOI: 10.1306/BDFF905A1718-11D7-8645000102C1865D

8. Распопов А.В., Хижняк Г.П. Обоснование коэффициента вытеснения нефти водой с привлечением результатов исследований объектованалогов // Геология, геофизика и разработка нефтяных и газовых месторождений. - 2009. - № 6. С. 39-43.

9. Хижняк Г.П. Комплексное решение проблемы оценки коэффициента вытеснения нефти в различных геолого-технологических условиях: автореф. дис. ... д-ра техн. наук. - Пермь, 2012.

10. Применение обобщенных петрофизических зависимостей при подсчете балансовых и извлекаемых запасов / Б.И. Тульбович, В.Г. Михневич, В.П. Митрофанов, В.Б. Бейзман, Г.П. Хижняк // Проблемы геологии и разработки нефтяных месторождений в районах с истощающимися ресурсами: сб. науч. тр. / БашНИПИнефть. - Уфа, 1989. - Вып. 79. - С. 117-123.
11. Impact of trapping of residual oil by mobile water on recovery performance in miscible enhanced oil recovery processes / P.R. Rampersad, D.O. Ogbe, V.A. Kamath, R. Islam // SPE - Rocky Mountain Regional/Low Permeability Reservoirs Symposium and Exhibition: Proceedings of the SPE Rocky Mountain Regional/Low Permeability Reservoirs Symposium and Exhibition / Society of Petroleum Engineers (SPE), Richardson, TX, United States. - Denver, 1995. P. 203-213. DOI: /10.2118/29563-MS

12. Хижняк Г.П. Петрофизические исследования динамических особенностей структуры порового пространства пород-коллекторов в связи с проблемами нефтеизвлечения (на примере залежей Пермского Прикамья): автореф. дис. ... канд. техн. наук. Пермь, 2000.

13. Carbonate reservoir rock typing - the link between geology and SCAL / J.S. Gomes, M.T. Ribeiro, C.J. Strohmenger, S. Negahban, M.Z. Kalam // SPE Proceedings of the 13th Abu Dhabi International Petroleum Exhibition and Conference, ADIPEC 2008. - 2008. Vol. 3. - P. 1643-1656. DOI: 10.2118/118284-MS

14. Опыт применения методики оценки коэффициента нефтевытеснения при проектировании разработки нефтяных месторождений Пермского края / Г.П. Хижняк, Т.Б. Поплаухина, С.В. Галкин, А.А. Ефимов // Геология, геофизика и разработка нефтяных и газовых месторождений. - 2009. - № 8. - С. 42-45.

15. Хижняк Г.П., Распопов А.В., Ефимов А.А. Методические подходы при обосновании коэффициента вытеснения нефти в различных геолого-физических условиях // Геология, геофизика и разработка нефтяных и газовых месторождений. - 2009. - № 10. - С. 32-35.

16. Способ определения коэффициента вытеснения нефти башкирских карбонатных отложений Башкирского свода: заявка на пат. № 028257 РФ, кл. МПК G01N 15/08 Рос. Федерация / Галкин В.И., Гладких Е.А., Хижняк Г.П.; заявитель и патентообладатель Галкин В.И., Гладких Е.А., Хижняк Г.П. - № 2017116297; заявл. 10.05.2017.

17. Способ определения коэффициента вытеснения нефти башкирских карбонатных отложений Соликамской депрессии: заявка на пат. № 028256 РФ, кл. МПК G01N 15/08 Рос. Федерация / Галкин В.И., Гладких Е.А., Хижняк Г.П.; заявитель и патентообладатель Галкин В.И., Гладких Е.А., Хижняк Г.П. - № 2017116296; заявл. 10.05.2017.

18. Johnson N.L., Leone F.C. Statistics and experimental design. - New York; London; Sydney; Toronto, 1977. $-606 \mathrm{p}$.

19. Montgomery D.C., Peck E.A. Introduction to linear regression analysis. - New York: John Wiley \& Sons, 1982. $-504 \mathrm{p}$. 
20. Tiab D. Modern core analysis. Vol. 1. Theory, core laboratories. - Houston, 1993. - 200 p.

21. Statistics for petroleum engineers and geoscientists [Электронный ресурс] / J.L. Jensen, L.W. Lake, P.W.M. Corbett, D.J. Goggin; ed. L.W. Lake. New Jersey: Prentice Hall PTR, 1997.

22. Houze O., Viturat D., Fjaere O.S. Dinamic data analysis. - Paris: Kappa Engineering, 2008. - 694 p.

23. Оценка коэффициентов извлечения нефти для месторождений Пермского края на основе статистических моделей / С.В. Галкин, Т.Б. Поплаухина, А.В. Распопов, Г.П. Хижняк // Нефтяное хозяйство. - 2009. - № 4. - С. 38-39.

24. Оценка эффективности воздействия кислотных составов на керны с использованием регрессионного анализа / В.И. Галкин, Г.П. Хижняк, А.М. Амиров, Е.А. Гладких // Вестник Пермского национального исследовательского политехнического университета. Геология. Нефтегазовое и горное дело. - 2014. № 13. - С. 38-48. DOI: 10.15593/2224-9923/2014.13.4

25. Галкин В.И., Пономарева И.Н., Репина В.А. Исследование процесса нефтеизвлечения в коллекторах различного типа пустотности с использованием многомерного статистического анализа // Вестник Пермского национального исследовательского политехнического университета. Геология. Нефтегазовое и горное дело. - 2016. - Т. 15, № 19. - С. 145-154. DOI: 10.15593/2224-9923/2016.19.5

26. Гладких Е.А., Галкин В.И., Хижняк Г.П. Об оценке коэффициента вытеснения нефти визейских терригенных отложений // Современные тенденции развития науки и технологий: материалы XXIV
Междунар. науч.-практ. конф., Белгород, 31 марта 2017 г. - Белгород, 2017. - № 3-2. - С. 62-66.

27. Девис Дж. Статистика и анализ геологических данных. - М.: Мир, 1977. - 353 с.

28. Чумаков Г.Н. Вероятностная оценка эффективности применения метода циклической закачки жидкости в пласт // Вестник Пермского национального исследовательского политехнического университета. Геология. Нефтегазовое и горное дело. - 2014. - № 13. C. 49-58. DOI: 10.15593/2224-9923/2014.13.5

29. Галкин В.И., Пономарева И.Н., Черепанов С.С. Разработка методики оценки возможностей выделения типов коллекторов по данным кривых восстановления давления по геолого-промысловым характеристикам пласта (на примере фаменской залежи Озерного месторождения) // Вестник Пермского национального исследовательского политехнического университета. Геология. Нефтегазовое и горное дело. - 2015. № 17. - С. 32-40. DOI: 10.15593/2224-9923/2015.17.4

30. Гладких Е.А., Галкин В.И., Хижняк Г.П. К вопросу определения коэффициента вытеснения нефти водой для визейских терригенных отложений месторождений Соликамской депрессии Пермского края // Новая наука: история становления, современное состояние, перспективы развития: сб. ст. междунар. науч.-практ. конф. - Пермь, 2017. - С. 211-213.

31. Гладких Е.А., Хижняк Г.П. Разработка модели для оценки коэффициента вытеснения нефти (на примере башкирских карбонатных отложений) // Нефтепромысловое дело. - 2017. № 5. - С. 9-14.

Please cite this article in English as:

Gladkikh E.A., Khizhnyak G.P., Galkin V.I., Popov N.A. Method for evaluation of oil displacement coefficient based on conventional core analysis. Perm Journal of Petroleum and Mining Engineering, 2017, vol.16, no.3, pp.225-237. DOI: 10.15593/2224-9923/2017.3.3

Просьба ссылаться на эту статью в русскоязычных источниках следующим образом:

Способ оценки коэффициента вытеснения нефти на основе стандартных исследований керна / Е.А. Гладких, Г.П. Хижняк, В.И. Галкин, Н.А. Попов // Вестник Пермского национального исследовательского политехнического университета. Геология. Нефтегазовое и горное дело. - 2017. - Т.16, №3. - C.225-237. DOI: 10.15593/2224-9923/2017.3.3 